\title{
A Set of Factors Related to the Opportunity Motivation: Analysis of Early-stage Entrepreneurs from SEE
}

\author{
Renata Amidžić \\ National Health Insurance Fund, Serbia
}

\begin{abstract}
This paper focuses on a set of factors related to the opportunity motivations of early-stage entrepreneurs, such as entrepreneur's perceptions and socio-demographic factors. The research area of this paper includes: fear of failure, social networking, entrepreneur's knowledge, skills and experience, and perception of business opportunity; and socio-demographic characteristics of entrepreneurs, such as the age, gender, level of education and household income. The data has been provided by Adult Population Survey, as part of the Global Entrepreneurship Monitor. The sample includes data collected in 2014, from 12,023 adults by interview methods, which implies valid answers of 692 early-stage entrepreneurs, i. e. a total of 415 early-stage entrepreneurs driven by opportunity motivation. The respondents are located in the Southeast Europe (SEE); and settled in six countries: Greece, Hungary, Romania, Croatia, Bosnia and Herzegovina and Slovenia. According to SPSS Statistics, the empirical research was processed using the Binomial Logistics Regression. Two hypotheses were set up to test the conceptual model. According to the theory and research results, the model consisted of determinants related to the opportunity motivations of early-stage entrepreneurs, has been developed. Motivation as a dependent variable has been measured by the TEA Opportunity index. Thus, the opportunity motivation is found to be related to the entrepreneur's perception, and socio-demographics factors. Determinants such as the fear of failure and perception of business opportunity contribute to a higher likelihood in the modelling opportunity motivation. The age, gender, level of education and household income also contributed to the developed model. The lower and middle household income of entrepreneurs, secondary degree education, gender as a male, and the entrepreneurs' age about 45-64 significantly added to the model prediction. Social networking and KSE's did not have a significant role on the entrepreneur's motivation according to the empirical results and the developed model. In addition to improving theoretical material from the field of entrepreneurship, the model also contributes to this work.
\end{abstract}

\section{Keywords}

Early-stage entrepreneurs, opportunity motivations, entrepreneur's perception, socio-demographic factors, Southeast Europe.

\section{Introduction}

Motivation for business is the main prerequisite for a successful venture. Starting from Maslow's Theory of needs to the recent research (e.g. by Baum \& Locke, 2004; Puente, Cervilla, Gonzalez, \& Auletta, 2017; Lecuna, Cohen, \& Chavez, 2017 and etc.), it has been noticed that the motivation theories have been developing predominantly as a process. The Global Entrepreneurship Monitor (GEM) has provided a wide range of aspects for empirical analysis by distinguishing two categories of motivations that can drive entrepreneurs, i. e. opportunity and necessity (Reynolds, Camp, Bygrave, Autio, \& Hay, 2001). Opportunity entrepreneurs are increase-wealthmotivated. They are looking for independence or new opportunity in business, by creating opportunities that can provide a wide range of business ventures on the market (Shane, Locke, \& Collins, 2003; Pinillos \& Reyes, 2011; Block \& Sandner, 2009). According to the motivation 
theories, they are "pulled" into business, in contrast to necessity entrepreneurs that are "pushed" (Stoner \& Fry, 1982; Gilad \& Levine, 1986; Reynolds et al., 2001; Bijaoui, 2012). Opportunity-motivated entrepreneurs have a higher chance of survival on the market, and they are better prepared for business entry than necessity entrepreneurs, because they start up business voluntarily (Block \& Sandner, 2009). Opportunities are also found to be a generator of maturity of entrepreneurial venture (Bobera, Leković \& Berber, 2017) or product of technological intensive environment that encourages entrepreneurial activity (Leković \& Marić, 2017). Furthermore, Verheul, Thurik, Hessels, and Zwan (2010) quote that the necessity motivated entrepreneurs differ from opportunity entrepreneurs in many ways; the difference arises from their socio-economic characteristics as well as motivation, which affect their business performance. Entrepreneurs differ in their abilities and willingness to achieve opportunities. They are wrapped in a variety of motivational factors that occur on their individual characteristics (Shane et al., 2003; Verheul et al., 2010). Theory and empirical knowledge about determinants related to the motivations are not unified; they vary over time. In addition, it has been noticed that many studies have explored the above mentioned topics during the past and the present century.

Therefore, following the mentioned field of research, the main purpose of this paper is to identify the determinants related to the motivation of early-stage entrepreneurs, who are seeking new chances and opportunities in business.

The aim of this paper is to conduct an exploratory analysis to evaluate the potential factors contributing to a higher likelihood of opportunity motivations. The advantage of the developed model is the sum of individual variables that have been included, which proves a wide range of conclusions. Regarding the available literature and recent empirical research, it has been noticed that the established models predominantly represent a view according to a particular country or country context, not the SEE; or it represents a majority of individual or contextual drivers related to the entrepreneurial motivations, applied also to specific industry sectors, products or services. The present research was created to overcome the limitations of previous research and thus to extend our knowledge of determinants related to the opportunity motivated entrepreneurs.
In this paper, we examined the following question: Do the individual characteristics such as perceptions (social networking, perception of business opportunity, knowledge, skill and experiences (KSE's) and fear of failure) and socio-demographic characteristics (age, gender, level of household income and education) related to the opportunistic motivation, in the case of early-stage entrepreneurs; do they contribute to a higher likelihood in the modelling opportunity motivation?

The Adult Population Survey (APS) as part of GEM project has provided the research data, which was collected in 2014 , by the interviewing method. The respondents are located in the SEE region, including six countries. The Binomial Logistics Regression model, processed by SPSS Statistics, was used to prove the set of hypotheses. According to theory, past empirical research, and the results of the empirical analysis, the model was developed, consisting of determinants related to the opportunity-motivated entrepreneurs.

This paper consists of several parts. The first, based on the theory and recent research investigates the sum of individual determinants, such as entrepreneurial perception and sociodemographic factors, related to the motivation of entrepreneurs driven by motives of opportunities. Two hypotheses were set up for the purpose of testing the conceptual model. In the last sections, the model was developed and some limitations and recommendations were presented in the end.

\section{Literature review}

Individual characteristics of entrepreneurs such as their perception (Bosma, Jones, Autio, \& Levie, 2008; Cacciotti \& Hayton, 2014; Block, Sandner, \& Spiegel, 2015; Rusu \& Roman, 2018) and socio-demographic characteristics, have been related to the factors of entrepreneurial motivation (DeTienne \& Chandler, 2007; Kautonen, 2008; Block \& Sander, 2009; Robichaud, 2010; Verheul et al., 2010; Wagner, 2005; Stephan, Hart, Mickiewicz, \& Drews, 2015). The next section presents a literature review of these factors.

\subsection{Factors of entrepreneur's perception related to the opportunity-motivated entrepreneurs}

Entrepreneur's perception has a significant role in the modelling of entrepreneurial motivations. In addition, perception relies on the entrepreneur's mechanism to interpret the reality (Giacomin, Janssen, \& Guyot, 2011). 
The fear of failure is one of the most frequently mentioned fears in the theory of entrepreneurship (Bosma et al., 2008). There are many definitions about the fear of failure through literature, but it is all different in one point of view: First, the fear of failure could be a crucial motivator for business, incorporated in the decision making of business. In contrast, it can be a barrier to entrepreneurial action, making entrepreneurs vulnerable and less adapted to unpredictable and risky situations. This restrictive approach can wrongly suggest that the fear of failure is not or should not be a part of entrepreneur's motivations (as a result of conceptual and methodological confusions), but recent observations suggest that both concepts should be accepted (Cacciotti \& Hayton, 2014). Therefore, the fear of failure must be considered as an interesting phenomenon and essential part of the entrepreneurial journey (Baron, 2008). Many authors that have been occupied with cognitive and behavioural responses (Sponte, 2018; Hardingham, Vrbka, Kliestik, \& Kliestikova, 2018), through the theory and empirical research have noticed that the fear of failure is an attitude toward risk (Verheul \& Mil, 2011; Hessels, Grilo, Thurik, \& van der Zvan, 2011). Similarly, the fear of failure has been defined as an attitude toward risk determined by high uncertainty of avoidance (Sandhu, Sidique, \& Shoaib, 2011). Some authors who advocate psychological approaches consider that the fear of failure is a negative emotion (Patzelt \& Shepherd, 2011) or negative anticipated emotions (Welpe, Sporrle, Grichnik, Michl, \& Audretsch, 2012). It can also be a feeling that leaves a decision maker discouraged about succeeding even before attempting (Ekore \& Okekeocha, 2012).

According to fear of failure and its relationship with motivation, Block et al. (2015) have analysed how the risk attitude differs among the opportunity and necessity entrepreneurs, and how the entrepreneurial motivation for work is associated with a risk attitude. They found that both types of entrepreneurs are motivated by opportunity and necessity motives to start their ventures; and their motivation sources are strongly associated with their attitude towards risk (i. e. fear of failure). In addition, opportunity motivated entrepreneurs that are also motivated by a high level of creativity are less risk averse than other entrepreneurs (Block et al., 2015). Similarly Wagner (2005), investigate how the fear of failure related to the nascent entrepreneurs motivated by opportunities, and nascent entrepreneurs motivated by necessity motives, for starting up a business. The empirical results showed that both types of entrepreneurs were hindered by risk aversion, but the nascent entrepreneurs motivated by opportunities and willingness to start their own business are more risk tolerant. Amit and Muller (1995), found that "pull" motivated entrepreneurs are risk averse, but their risk attitudes are similar to "push" motivated entrepreneurs even when variables like the age, gender or education of entrepreneurs were included. Furthermore, Morgan and Sisak (2015) suggest that the fear of failure can have motivating effects on a highly ambitious entrepreneur (i. e. opportunity motivated entrepreneurs), but it can also have demotivating effects on someone less ambitious.

According to the above, we suggest that the fear of failure can explain motivation of entrepreneurs, with special emphasis on opportunity-motivated entrepreneurs.

Since the mid-eighties, the recognition of the importance of involving entrepreneurs in social networks has experienced a revival (Hansen, 1995; Cooper, Folta, \& Woo, 1995; Christensen \& Peterson, 1990). The approach of social networks as a dynamic process has provided the researchers with a variety of fields for exploration. Christensen and Peterson (1990) argue that social networks are an important source of new ideas. The social networks approach also showed that individual entrepreneurs are socially embedded entrepreneurs and the fact is that individuals may differ in terms of social contacts (Barnes, 1975). However, the latest study explores how social networks affect the various entrepreneurial issues, but less explains whether they affect it; the study explored either a specific sector of industries; or the impact of social networks in different country context (Arenius \& Clerck, 2005; Klyver \& Hindle, 2014).

Social networks can help entrepreneurs to provide business success by achieving their goals, and valuable resources, that they do not yet possess (Jenssen \& Greve, 2002; Jenssen \& Koenig, 2002; Klyver \& Hindle, 2014). The development of social networks opens new opportunities (Slavić, Bjekić \& Berber, 2017). Thus, through the connection of different social relations, the social networks can provide different resources to entrepreneurs, such as information, access to finance, access to skills, knowledge or access to social legitimacy (Klyver 
\& Hindle, 2014). Earlier research showed that the social networks were the leading path for achieving the opportunities (Hills, Limpkin, \& Singh, 1997, Ardichvii \& Cordozo, 2000), and also a bridge of strong ties in the process of achieving information resources (Granovetter, 1973). Hills et al. (1997) conclude that entrepreneurs will achieve more opportunities only in situations when they work on developing social networks according to business (i. e. opportunity entrepreneurs), contrary to entrepreneurs who avoid or have a lack of networks (i. e. necessity entrepreneurs). According to the previous research, Ardichvili and Cordozo (2000) have a hypothesis that successful identifications in business are associated with extending social networking. The result of their research supports a strong relationship between these two observed parameters. In addition, they conclude that the opportunity motivation (i. e. recognition) has been determined by entrepreneurial networks, entrepreneurial alertness, and prior knowledge of markets and customer problems. Furthermore, Arenius and Clerck (2005) have examined in their study how social networks affect entrepreneurial opportunities according to the type of network and to the extent to which entrepreneurs have been potentially exposed to social networks. They found that the nature of living area such as a big city can provide more opportunities and new ideas (vs. rural area), by connecting with various institutions (universities, research facilities etc.) and individuals. Furthermore, according to current research that observes early-stage entrepreneurs involved in TEA stage, it is noteworthy to mention the research by Klyver and Hindle (2014), who found that structural diversity in social networks differs during the different stages of the entrepreneurial process. It is most important for entrepreneurs in the discovery stage, less important in the start-up stage and moderately important for entrepreneurs in the young business stage.

Therefore, according to the literature review about social networks and the willingness of the entrepreneur to embed it, we suggest that positive perception about social networking is crucial for performing the opportunity motivation.

Arenius and Minnity (2005) in their study that implies the nascent entrepreneurs have demonstrated that there is a high correlation between entrepreneurial skill, knowledge of other entrepreneurs, existence of opportunities, and entrepreneurial motivation to start a new business. They also argue that entrepreneurs tend to rely relatively more on perception than on objective features.

Boudreaux, Nikolaev, \& Klein (2019) found that entrepreneurs with a higher level of selfefficacy are more motivated to start-up a business. Thus, the psychology literature has established the importance of entrepreneurial confidence and perception, based on entrepreneur's own skills (i. e., Social Learning Theory), also named the concept of self-efficacy (Arenius \& Minnity, 2005; El-Hadary, 2018). El-Hadary (2018) argues that self-efficacy can affect the persistence of entrepreneurs to establish or manage a new venture. In addition, according to their previous engagement in business, the self-efficacy referred to opportunity-motivated entrepreneurs (Suchart, 2017), contrary to necessity entrepreneurs that have lower knowledge, skills and experience. The entrepreneurs' perception of possessing certain skills is in correlation with the level of their selfconfidence. Possession of different skills is important to an entrepreneur in order to be more successful. Opportunity entrepreneurs have more confidence in their skills, because they voluntarily entered the job, and were more prepared for new ventures. According to Genty, Idris, Wahat, \& Kadir (2015), entrepreneurial experience refers to "the previous number of years and role played by entrepreneurs in their former ventures". The experience includes the time during which the entrepreneur was a manager of the firm, and made decisions that are important for business. The experience can be gained both in the initial phase of the business, or in the mature age of firms. According to the presented, we suggest that the entrepreneur's knowledge, skills and experience can explain the motivation of early-stage entrepreneurs, with special emphasis on opportunity-motivated entrepreneurs

The omnibus of literature considers entrepreneurship as a creative process (Shane \& Venkataraman, 2000; Shane et al., 2003) in which entrepreneurs tend to achieve the opportunities from business (Linan, Santos, \& Fernandez, 2011; Suchart, 2017; Boudreaux et al., 2019). Perception of business opportunity as one of the entrepreneurial capabilities is based on the Theory of Planned Behaviour which implies various consequences on the entrepreneur's behaviour. Thus, entrepreneurs differ from each other in a situation while they need to recognize the opportunities of the business (Suchart, 2017). 
Suchart (2017) explored the relationship between the individual characteristics of nascent opportunity and nascent necessity entrepreneurs, and found that opportunity recognition can enhance the likelihood of becoming the nascent entrepreneurs, motivated by opportunity determinants. Boudreaux et al. (2019) found that entrepreneur's alertness to perceive business opportunities can promote entrepreneurial action and entrepreneur's motivation to start up a business. The notice can be applied to countries where the economy system is at the higher level of development. Thus, the perception of business opportunity is a cognitive process, whereas the perception of entrepreneurs relies on their capabilities to perceive the opportunities of business (Linan, Santos, \& Fernandez, 2011).

According to presented data, we assume that:

H1: Entrepreneur's perception related to the opportunity motivation of early-stage entrepreneurs; entrepreneur's perception contributes to a higher likelihood in the modelling opportunity motivation.

\subsection{Socio-demographic characteristics of entrepreneurs related to the opportunity- motivated entrepreneurs}

The aim of the next section of the literature review is to analyse recent empirical research, about socio-demographics factors related to the opportunity-motivated entrepreneurs, such as entrepreneur's age, gender, and the level of education and household income.

Verheul et al. (2010) confirmed that the opportunity entrepreneurs vs. necessity entrepreneurs are in a negative correlation according to age. Thus, young entrepreneurs at the beginning of their career tend to manage business driven by opportunity motives. Young entrepreneurs have low commitments (family, financial etc.), and they are more likely to search for good career and business opportunities. Entrepreneurs in their mid-40s are less opportunity-oriented than the older entrepreneurs aged over 50, who have a strong willingness to seek new opportunities and business advantage. Older entrepreneurs have less commitment (i. e. family and childcare obligations tend to be less intensive) than young entrepreneurs, and their focus is mainly on business by seeking opportunities (Stephan et al., 2015). Block and Sander (2009) found that: 1) opportunity entrepreneurs are slightly younger than the necessity entrepreneurs; 2) chances that an entrepreneur is opportunity motivated decrease with age. Furthermore, Robichaud, LeBresseur, and Nagarajan (2010), have shown that the opportunity entrepreneurs are younger, but also more educated, have good skills and a high level of propensity to anticipate future opportunities. Kautonen (2008) in their study also confirm that the older entrepreneurs are motivated by opportunity motives. On the other hand, some research has shown that the older entrepreneurs are less motivated than young entrepreneurs, i. e. older entrepreneurs are less likely to engage in business (Curran \& Blackburn, 2001).

Recent research shows that a woman's motives for entrepreneurship rely on the relationship between her working conditions and work-family conflict (Greve \& Salaff, 2003). Women have more preferences for correlating family and job, compared, as opposed to men (DeMartino \& Barbato, 2003). Therefore, if a woman is not satisfied with settled terms and conditions, she is more able to search for a new job by engaging in new business. Buttner and Moore (1997) suggest that women are seeking new opportunities in business, in order to create a more pleasant working environment. Women also tend to control their working environment to achieve the advancement opportunities. Carter, Shaw, Lam, \& Wilson (2003) found that men are more motivated for financial success than women, who are more driven by independence motives. DeTienne and Chandler (2007) argue that men and women use different opportunity identification according to the business process. Men have higher expectations than women do (Gatewood, Shaver, \& Gartner, 1995). Similarly, men have considered that they are suitable candidates for entrepreneurship, i. e. opposite to woman views (Malach-Pines \& Schwartz, 2008). Pulled motives for a man reported higher income and profit than women (Watson, 2002). In general, research findings suggest that women are more necessity oriented, than men, who are more opportunity oriented.

Socio-demographic characteristics, especially education, show association with a range of motivations. Verheul et al. (2010) found that the level of education has positively related to engagement in opportunity-driven entrepreneurial activities. They suggest that education can be important for pursuing business opportunities, and, according to research parameters, the level of education has been found to be reducing odds of failure in case of opportunity entrepreneurs. Thus, 
Stephan et al. (2015) add that the influence of education on entrepreneurial motivation is very complex, and it depends on gender and age. Block and Sandner (2009) found that opportunity entrepreneurs are well educated in the field in which they set up a business. Higher educated entrepreneurs have lower chance to be necessity motivated. Verheul et al. (2015) have noticed that opportunity entrepreneurs are more specific than the necessity entrepreneurs are. Entrepreneurs that have higher level of education such as secondary degree or graduate experience have more alternatives for work, and more chances to be opportunity motivated. Wagner (2005) also highlights that there is a significant and positive relationship between the opportunity nascent entrepreneurs and the level of education. The higher the level of education is the more likely is an entrepreneur to be opportunity-motivated.

In conditions of start-ups, women have been motivated by less capital than men (Boden \& Nucci, 2000; Watson, 2002). Thus, recent research has shown that women have a significantly lower household income than men (Jones \& Tullous, 2002; Jennings \& Mc Dougald, 2007; Cron, Gilly, Graham, \& Slocum 2009). Entrepreneurs with higher household income are more likely to seek new opportunities from business, and pursue more opportunities. By contrast, entrepreneurs with lower household income are more likely to be necessity motivated. Higher income allows entrepreneurs more financial independence in the process of gaining opportunities from business. Necessity motivated entrepreneurs are more concerned about contributing the money to households (Stephan et al., 2015).

According to the presented data, we assume that:

$\mathrm{H} 2$ : Socio-demographic factors such as age, gender, level of education and the level of household income related to the opportunity motivation of early-stage entrepreneurs; sociodemographic factors contribute to a higher likelihood in the modelling opportunity motivation.

\section{Methodology}

The data for the empirical research has been provided by Global Entrepreneurship Monitor (GEM), Adult Population Survey (APS). The GEM is one of the largest international academic research projects of entrepreneurship. GEM has a wide range of views on entrepreneurship and primarily considers the extent to which individuals are involved in entrepreneurial activities within the country, identifying different types and stages of entrepreneurship (Puente et al., 2017). The GEM project includes the monitoring of entrepreneurial activities, using three main indicators: Total early-stage entrepreneurial activity (TEA), the proportion of established businesses among the respondents and entrepreneurial employee activity (GEM, 2018). TEA is the key phase for the most entrepreneurs (Ciravegna, Kuivalainen, Kundu, \& Lopez, 2018), and according to GEM methodology implies: entrepreneurs in the phase that combines the stages before the start of a new firm, nascent entrepreneurs that settled a business, and pay the wages at least 3 months; entrepreneurs as owning managers of a new business that paid wages in continuity of 42 months (Reynolds et al. 2001; Reynolds, Carter, Gartner, \& Greene, 2004; Wagner, 2004; Stephan et al., 2015). Nascent entrepreneurs make initiation activities, while the new business owners are entrepreneurs involved in the stage directly after the start of a new firm. The sample includes data collected in the year 2014 , from 12,023 adults by interview methods, which implies valid answers of 692 early-stage entrepreneurs, i. e. total 415 early-stage entrepreneurs driven by opportunity motivation. Research data implies individual answers from a random sample of adults aged 18-64. The respondents are located in the SEE region, settled in the following six countries: Greece, Hungary, Romania, Croatia, Bosnia and Herzegovina and Slovenia. Thus, Serbia, Montenegro, Macedonia and Bulgaria did not participate in GEM project in 2014.

Furthermore, the empirical model has been made for the purpose of empirical research. Models obtain the predictive categorical variables (social networking, perception of business opportunity, fear of failure, KSE's, age, gender, household income and education) and one dichotomous dependent variable. TEA: opportunity (in a sample of early-stage entrepreneurs) as dependent variable represents the percentage of adults aged 18-64 who are involved in business driven by opportunity motives.

In order to research a set of hypotheses, SPSS Statistics and Binomial Logistics Regression has been used to analyse the data - it predicts the explanation or probability that observations fall into one of two categories of dichotomous 
criterion variable based on a set of predicting variables (Hosmer \& Lemeshow, 2000). In addition, this method enabled us to identify which determinants were the most important in categorizing opportunity motivations. Dependent variable has been measured on a dichotomous scale. Social networking has been measured on a dichotomous scale, which takes value 0 for No, and 1 for Yes, according to the answers to the question: Do you personally know someone who started a business in the past 2 years? The perception of business opportunity has been measured on a dichotomous scale, which takes value 0 for No, and 1 for Yes, according to the answers to the question: In the next six months, will there be good opportunities for starting a business in the area where you live? KSE's has also been measured on a dichotomous scale, according to the question: Do you have the knowledge, skills and experience required to start a new business? Fear of failure has also been measured on a dichotomous scale, according to the question: Would fear of failure prevent you from starting a business? Household income is set as the average variable, which takes the value 1 for the lowest, 2 for middle and 0 for the upper household income. Furthermore, education as predicted and ordinary variable, takes the value 1 for none, 2 for some secondary, 3 for secondary degree and 4 for graduate experience. Gender as a dichotomous variable takes the value 1 for male and 0 for female. The age as predicted variable, measures the age of adults that are recoded into the groups 0 (18-24), 1 (25-34), 2 (35-44), 3 (45$54)$ and 4 (55-64).

\section{Results and discussion}

The first step of the research involves the observation of all the variables in the model in order to achieve the explanation, and probability of the TEA: opportunity. A Binomial Logistic Regression has been performed to determine the effects of the entrepreneur's perception and sociodemographic characteristics on the likelihood that early-stage entrepreneurs are motivated by opportunities. Table 1, contain correlation matrix, and none of correlations appear to be large; thus the multicollinearity is not present. Table 2, contain estimates of the logistic coefficient, identified as predictors in block one (column B). In the same column, Constant is specified. Asymptotic standard errors for individual logistic coefficients have been represented in column "S.E". The column "Wald" contains the results of the Wald statistics and chi-square test, column "df" as the degrees of freedom and the column "Sig" represents the probability from the Wald test hypothesis that the logistic coefficient for the predictor variable is equal to zero. The column "Exp (B)" contains all exponential logistic coefficients that are important for the interpretation of logistics regression.

The logistic regression model was statistically significant, $\chi^{2}(8)=103.480, p<.0005$. The explained variation in the dependent variable was based on ranges from $13.9 \%$ to $18.8 \%$ according to Cox \& Snell R2 or Negelkerke R2 methods. Respectively, Negelkerke is a modification of Cox \& Snell, so in this study we report Negelkerke R2. Therefore, the model explained $18.8 \%$ of the variance in opportunity motivations and correctly classified $66.9 \%$ of the cases. According to the Wald test (which is used to determine statistical significance, for each of the independent variables), the statistical significance of the test was found. 1) Determinants such as the lower household income $(p=.000)$, middle household income $(p=.041)$, secondary degree $(p=.017)$, perception of business opportunity $(p=.033)$, fear of failure $(\mathrm{p}=.004)$, male gender $(\mathrm{p}=.015)$, and age between 55 and $64(\mathrm{p}=.010)$, added significantly to the model. 2) Other determinants such as social networking or KSE's did not significantly add to the model. According to the probability predicting of an event occurring, based on a one-unit change in an independent variable, we can emphasize that the odds of opportunity motivations are 1.561 times higher for males than for females. Increasing age and the household income are more likely to be associated with a reduction in the likelihood of opportunity motivations. Opportunity entrepreneurs have a 1.471 times higher perception of business opportunity than non-opportunity entrepreneurs. The fear of failure was associated with a reduction in the likelihood of opportunity motivation. 
Table 1 Correlations matrix

\begin{tabular}{|c|c|c|c|c|c|c|c|c|c|}
\hline Variables & 1 & 2 & 3 & 4 & 5 & 6 & 7 & 8 & 9 \\
\hline Opportunity motivation & 1 & & & & & & & & \\
\hline Social networks &, $133^{* *}$ & 1 & & & & & & & \\
\hline Perception of business opp. &, $136^{* *}$ & $155^{* *}$ & 1 & & & & & & \\
\hline KSE's &, $094^{\star \star}$ &, $222^{* *}$ &, $070^{* *}$ & 1 & & & & & \\
\hline Fear of failure &,$- 162^{* *}$ &,$- 070^{* *}$ &,$- 094^{* *}$ &,$- 108^{* *}$ & 1 & & & & \\
\hline Household income &, $234^{* *}$ &, $155^{* *}$ &, $074^{* *}$ &, $124^{* *}$ &,$- 100^{* *}$ & 1 & & & \\
\hline Education &, $200^{* *}$ &, $145^{* \star}$ &, $066^{* *}$ & $169^{* *}$ &,- 012 &, $304^{* *}$ & 1 & & \\
\hline Age &,- 060 &,$- 092^{* *}$ &,$- 052^{* *}$ &,- 006 &,- 004 &,$- 064^{* *}$ &,$- 106^{* *}$ & 1 & \\
\hline Gender &,$- 077^{*}$ &,$- 098^{* *}$ &,$- 041^{* *}$ &,$- 168^{* *}$ &, $094^{* *}$ &,$- 084^{* *}$ &,- 017 &, $023^{*}$ & 1 \\
\hline
\end{tabular}

Table 2 Results of the Binomial Logistics Regression

\begin{tabular}{|c|c|c|c|c|c|c|}
\hline Predicted variables & B & S.E. & Wald & df & Sig. & $\operatorname{Exp}(B)$ \\
\hline \multicolumn{7}{|l|}{ Entrepreneurs perception } \\
\hline Social networking & 204 & ,176 & 1,334 & 1 & ,248 & 1,226 \\
\hline Perception of business opportunity & ,386 & 181 & 4,552 & 1 & 033 & 1,471 \\
\hline KSE'S & ,278 & ,231 & 1,447 & 1 & ,229 & 1,321 \\
\hline Fear of failure &,- 516 & ,178 & 8,384 & 1 & ,004 &, 597 \\
\hline \multicolumn{7}{|l|}{ Socio-demographic factors } \\
\hline Upper household income & & & 18,422 & 2 & ,000 & \\
\hline Lower household income &,- 931 & ,218 & 18,279 & 1 &, 000 & ,394 \\
\hline Middle household income &,- 432 & ,212 & 4,178 & 1 & ,041 & ,649 \\
\hline Gradual exp. Education & & & 24,950 & 4 &, 000 & \\
\hline None education &,- 528 & ,715 &, 545 & 1 &, 460 &, 590 \\
\hline Some secondary education &,- 557 & ,441 & 1,597 & 1 & 206 & ,573 \\
\hline Secondary degree education &,- 858 & ,360 & 5,672 & 1 & ,017 &, 424 \\
\hline Postsecondary degree &, 060 & ,363 & ,027 & 1 & ,870 & 1,061 \\
\hline Gender(male) &, 445 & 183 & 5,936 & 1 & ,015 & 1,561 \\
\hline Age 18-24 & & & 13,423 & 4 &, 009 & \\
\hline Age 25-34 &,- 249 & ,270 & ,856 & 1 & ,355 & ,779 \\
\hline Age 35-44 &,- 390 & ,271 & 2,070 & 1 &, 150 & ,677 \\
\hline Age 45-54 & ,234 & ,299 & ,613 & 1 &, 434 & 1,264 \\
\hline Age 55-64 &,- 908 & ,354 & 6,585 & 1 & ,010 &, 403 \\
\hline Constant & ,906 &, 495 & 3,350 & 1 & ,067 & 2,474 \\
\hline \multicolumn{7}{|l|}{ Statistical information } \\
\hline-2 log likelihood & & & $823,130^{a}$ & & & \\
\hline$\chi^{2}$ & & & 103.480 & & & \\
\hline (df) & & & 8 & & & \\
\hline Negelkerke R2 & & & 18,8 & & & \\
\hline Overall predicted accuracy \% & & & $66,9 \%$ & & & \\
\hline Case processing summary & & & 692 & & & \\
\hline Number of observations & & & 415 & & & \\
\hline
\end{tabular}

Source: Authors analysis in SPSS, based on GEM data

See Table 1 and Table 2 for the previous discussion. The second step of the research might imply the observation of the significant determinants as pronounced and defined in Table 2. The model can include a lower number of significant predictors, and it can be simpler than the previous one (Hosmer \& Lemeshow, 2000).

In this analysis, we did not run a further step of the binomial logistics regression.

\section{Conclusion and recommendations}

Following the results of the research, and apart from the fact that only a limited number of authors have examined the individual determinants related to the opportunity motivations in the case of early-stage entrepreneurs (Arenius \& Minnity, 2005; Wagner, 
2005; Suchart, 2017; Rusu \& Roman, 2018), this paper has a few important contributions.

Firstly, research results showed that entrepreneurial perception plays a relatively significant role in modelling entrepreneurial motivation of early-stage entrepreneurs. Thus, social networking and KSE's did not have a significant role in modelling entrepreneur's motivation, as opposed to the results of determinants such as fear of failure and perception of business opportunities that contribute to a higher likelihood in the modelling opportunity motivation. In addition, the hypothesis $\mathrm{H} 1$ was partially confirmed, and two determinants, out of four, related to the motivation. Fear of failure as predictor's variable related to the opportunity motivation, was confirmed once more in an empirical research (Wagner, 2005; Morgan \& Sisak, 2015; Block, 2015), showing that the role of fear of failure is not negligible. In addition, the business environment of the SEE has specific business conditions (i. e. countries with predominantly lower development economy), so it is important to mention that an increasing number of small and medium-size entrepreneurs tend to find their business chances pursuing opportunities. But, the past legacy and the long period of reforms, has left a mark on the entrepreneur's perception of the fear of failure. Thus, the fear of failure can also be a positive cognition, making entrepreneurs alert and prepared for different business terms. It would be desirable to include governments in the business environment of small and medium-sized enterprises in order to provide their support programs (e.g. about start-ups, decision support, logistic and administrative support etc.). Thus, early-stage entrepreneurs would perceive greater affiliation and social cohesion, thanks to having less fear of failure in business.

Secondly, the results of empirical research suggest that early-stage entrepreneurs, motivated by opportunities, have a greater perception of business opportunities. Thus, the results of research show that opportunity motivated entrepreneurs, such as nascent and new business owners, have initial cognitive ability to recognize opportunity that enables them to seek new chances in business. They are motivated by the motives of independence (i. e. autonomy), and also have the abilities and willingness to achieve the opportunities. Perception of business opportunities seems to be a more desirable characteristic of entrepreneur's perception than the fear of failure is, but both have an important role, according to empirical research of this paper. Perception of business opportunities tends to have a wide range of views, but generally speaking it reflects the entrepreneur's alertness (Linan, Santos, \& Fernandez, 2011; Suchart, 2017; Boudreaux et al., 2019) and confidence to grab the opportunities from business.

Thirdly, the results of Logistics Regression did not show contribution of determinants, such as social networking and KSE's, on early-stage entrepreneurs that are forced by opportunity motivation. These two determinants did not add significantly to the model. It does not necessarily mean that those two determinants are not related to the motivation of entrepreneurs, or do not relate to the necessity entrepreneurs, the results showed that no relation exists in the case of the opportunity entrepreneurs in TEA stage, that are involved in business in the area of SEE. We leave that dilemma and discussion for someone new researching, with recommendation to run regression, including opportunity motivation separately for nascent opportunity entrepreneurs, and also for opportunity new business owner's entrepreneurs. Some further research should also include statistics analysis with time flow i. e. more than a year.

Fourthly, research results showed that sociodemographic factors play a significant role in modelling entrepreneurial motivation of earlystage entrepreneurs. Four determinants were set up, and all four added significantly to the model prediction. They successfully explained the probability of the tested model. Thus, the hypothesis $\mathrm{H} 2$, that: socio-demographic factors related to the opportunity motivation of earlystage entrepreneurs, and also contribute to a higher likelihood in the modelling opportunity motivation, have been confirmed. Thus, the earlystage entrepreneurs, predominantly male, aged about 55-64, with secondary degree education, who have lower or middle household income, are driven by opportunity motivations according to empirical results. It may be unusual that older entrepreneurs aged 55-64 added significantly to the model prediction, but if we take into consideration that older entrepreneurs have less commitment (i. e. family and childcare obligations tend to be less intensive), the conclusion seems to be found. Perhaps the discouraging results are that men are mostly driven by opportunity motivation, and the role of a woman in this case does not seem to be 
recognizable. The recommendation observes more encouragement for the entrepreneurship lead by a woman.

Recent research has shown the significant role of the higher level of education in modelling the opportunity motivation of entrepreneurs (Wagner, 2005; Sandner, 2009; Verheul et al., 2015). In addition, a higher level of education means that an entrepreneur is more likely to be opportunitymotivated. Our findings showed different results. Thus, the level of education, such as secondary degree according to our findings, has a significant role in modelling the opportunity motivation. That seems to tell us that the entrepreneurs with higher level of education should be more opportunity motivated, in line with findings in developed countries. The recommendations according to this part of research should be to include (for someone doing further research), education should be used as a prediction variable in the case of nascent opportunity entrepreneurs, as well as new business owners, motivated by opportunities. The results may be more specified.

The level of household income, such as lower and middle income, added significantly to the model prediction. The recent results have shown that the entrepreneurs with higher household income are more likely to seek new business chances, and to pursue more opportunities (Stephan et al., 2105). Our findings differ from the previous one. It can be explained with generally lower development economy of SEE region, where the wages are at the lower level. So, the entrepreneurs with lower and middle income tend to be opportunity motivated, which could be interpreted as an advantage.

The developed model contains a set of factors that added significantly to the model's prediction. Thus, the entrepreneur's perception (fear of failure and perception of business opportunities), and socio-demographics factors (such as age, gender, household income and the level of education) related to the opportunity motivation of early-stage entrepreneurs, and also contribute to a higher likelihood in the modelling opportunity motivation. In addition to improving theoretical material from the field of entrepreneurship, the developed model also contributes to this work.

Recommendations for further empirical research rely on: 1) including more determinants related to the opportunity motivation, such as entrepreneurial attitudes and intentions; or organizational factor, environmental factors etc.
2) empirical analysis should include other entrepreneurial stage of activity, such as established entrepreneurial stage 3) research can be extended to the necessity entrepreneurs, including all presented determinants; determinants related to opportunity motivations might be compared with necessity.sm

\section{References}

Amit, R., \& Muller, E. (1995). „Push“ and „Pull“ Entrepreneurship. Journal of Small Business Entrepreneurship, 12(4), 64-80. https://doi.org/10.1080/08276331.1995.10600505

Ardichvili, A., \& Cordozo, N. R. (2000). A model of the entrepreneurial opportunity recognition process. Journal of Enterprising Culture, (2), 103-119. https://doi.org/10.1142/S0218495800000073

Arenius, P., \& Clercq, D. (2005). A Network-based Approach on Opportunity Recognition. Small Business Economics, 24, 249-265. https://doi.org/10.1007/s11187-005-1988-6

Barnes, J. (1972). Social Networks. Philippines: AddisonWesley.

Baron, R. (2008). The role of affect in the entrepreneurship process. Academy of Management Review, 33, 328340. https://doi.org/10.5465/amr.2008.31193166

Baum, J. R., \& Locke, E. A. (2004). The Relationship of Entrepreneurial Traits, Skill, and Motivation to Subsequent Venture Growth. Journal of applied Psychology, 89(4), 587-598. https://doi.org/10.1037/0021-9010.89.4.587

Bijaoui, I. (2012). From necessity business entrepreneurship: The case of the Songhai centre, Porto Novo, Benin. African Journal of Business Management, 6(18), 5872-5878. https://doi.org/10.5897/AJBM12.302

Block, J., Sandner, P., \& Spiegel, F. (2015). How do Risk Attitudes Differ within the Group of Entrepreneurs? The role of Motivation and Procedural Utility. Journal of Small Business Management, 53(1), 183-206. https://doi.org/10.1111/jsbm.12060

Block, J. H., \& Sandner, P. (2009). Necessity and opportunity entrepreneurs and their duration in selfemployment: evidence from German micro data. Journal of Industry, Competition and Trade, 9(2), 117137.

https://doi.org/10.1007/s10842-007-0029-3

Bobera, D., Leković, B., \& Berber, N. (2017). The relationship between motives of entrepreneurial behaviour and venture maturity. Industrija 45(1), 81-97. https://doi.org/10.5937/industrija45-11201

Boden, R. J., \& Nucci, A. R. (2000). On the survival prospects of men's and women's new business ventures. Journal of Business Venturing, 15(4), 347362. https://doi.org/10.1016/S0883-9026(98)00004-4

Bosma, N. S, Jones, K., Autio, E., \& Levie, J. (2008).Global Entrepreneurship Monitor; 2007 Executive Report. Babson College, London Business School, and Global Entrepreneurship Research Association

Boudreaux, J. C., Nikolaev, B. N, \& Klein, P. (2019). Sociocognitive traits and entrepreneurship: The moderating role of economic institutions. Journal of Business 
Venturing, 34(1),178-196.

https://doi.org/10.1016/j.jbusvent.2018.08.003

Buttner, E. H., \& Moore, D. P.(1997). Women's organizational exodus to entrepreneurship: selfreported motivations and correlates with success. Journal of Small Business Management, 35(1), 34-46.

Caccioti, G., \& Heyton, C. J. (2014). Fear of Failure and Entrepreneurship: A review and Direction for Future research. Enterprise Research Centre. Research paper, 24.

Carter, S., Shaw, E., Lam,W., \& Wilson, F. (2007).Gender, entrepreneurship and bank leading: the criteria and process used by bank loan officers in assessing applications. Entrepreneurship, Theory and Practice, 31(3), 427-444. https://doi.org/10.1111/j.1540-6520.2007.00181.x

Christensen, P., S. \& Petrson, R. (1990). Opportunity Identification: Mapping the Sources of New Venture Ideas. Frontiers of Entrepreneurship Research. Wellesley, MA: Babson College, 567-581.

Ciravegna, L., Kuivalainen, O., Kundu, K.S., \& Lopez, E. L. (2018). The antecedents of early internationalization: A configurationally perspective. International Business Review, 1-13.

https://doi.org/10.1016/j.ibusrev.2018.05.002

Cooper, A. C., Folta, T. B., \& Woo, C. (1995). Entrepreneurial information search. Journal of Business Venturing, 10(2), 107-120. https://doi.org/10.1016/0883-9026(94)00022-M

Cron, W. L., Gilly, M.C, Graham, J. L., \& Slocum, J. W. (2009). Gender differences in pricing of professional services: implications for income and customer relationships. Organizational Behaviour and Human Decision Process, 109(1), 93-105. https://doi.org/10.1016/j.obhdp.2008.11.004

Curran, J., \& Blackburn, R. (2001). Older people and the enterprise society: Age and self-employment propensities. Work, Employment and Society, 15, 889902. https://doi.org/10.1177/095001701400438279

De Martino, R., \& Barbato, R. (2003). Differences between woman and man MBA entrepreneurs: exploring family flexibility and wealth creation as career motivators. Journal of Business Venturing, 18(6), 815.832. https://doi.org/10.1016/S0883-9026(03)00003-X

DeTienne, D. R., \& Chandler, G. N. (2007). The role of gender in opportunity identification. Entrepreneurship, Theory and Practice, 31(3), 365-386. https://doi.org/10.1111/j.1540-6520.2007.00178.x

Ekore, J. O., \& Okekeocha, O. C. (2012). Fear of entrepreneurship among university graduates: a psychological analysis. International Journal of Management, 29(2), 515-524.

El-Hadary, E. T.(2018). Gender, Perceptual factors, and Entrepreneurisl Intention: Evidence from Egypt. School og global Affairs and Public policy: The American University in Cairo.

Gatewood, E. J., Shaver, K. G., \& Gartner, W. B. (1995). A longitudinal study of cognitive factors influencing startup behaviours and success at venture creation. Journal of Business Venturing, 10(5), 371-391. https://doi.org/10.1016/0883-9026(95)00035-7

Global entrepreneurship Monitor (2018). Global Report 2017/2018. Babson college.

Genty, K. Idris, K., Wahat, N. W., \& Kadir, S. (2015). Demographic Factors and Entrepreneurial Success: A
Conceptual Review. International Journal of Management Sciences, 6(8), 366-374.

Giacomin, O., Janssen, F., \& Guyot, J. (2011). Opportunity and/or necessity entrepreneurship? The impact of the socio-economic characteristics of entrepreneurs. Munich Personal RePEc Archive. Paper No. 29506.

Gilad, B., \& Levine, P. (1986). A behavioural model of entrepreneurial supply. Journal of small business management, 24(4), 45-54.

Granovetter, M. (1973). The Strength of Weak Ties. American Journal of Sociology. 78(6), 1360-1380. https://doi.org/10.1086/225469

Greve, A., \& Salaff, J. W. (2003). Social networks and entrepreneurship. Entrepreneurship, Theory and Practice, 28(1), 1-22. https://doi.org/10.1111/1540-8520.00029

Hansen, E. L. (1995). Entrepreneurial network and new organization growth. Entrepreneurship: Theory \& practice, 19(4), 7-19. https://doi.org/10.1177/104225879501900402

Hardingham, E., Vrbka, J., Kliestik, T., \& Kliestikova, J. (2018). Will Cognitive Technology-Driven Automation Lead to Economic Growth?Journal of Self-Governance and Management Economics 6(4),13-18. https://doi.org/10.22381/JSME6420182

Hessels, J., Grilo, I., Thurik, R., \& van der Zvan, P. (2011). Entrepreneurial exit and entrepreneurial engagement. Journal of Evolutionary Economics, 21,447-471. https://doi.org/10.1007/s00191-010-0190-4

Hills, G. E., Limpkin, G. T., \& Singh, R. P. (1997). Opportunity recognition. Perception and Behaviours of Entrepreneurs. Frontiers of Entrepreneurs Research. Wellesley, MA: Babson College.

Hosmer, D. W., \& Lemeshow, S. (2000). Applied logistic regression (2nd ed.). New York: Wiley. https://doi.org/10.1002/0471722146

Jennings, J. E. \& McDougald, M. S. (2007). Work- family interface experiences and coping strategies:implictions for entrepreneurship research and practice. Academy of Management Rewiev, 32(3), 747-760. https://doi.org/10.5465/amr.2007.25275510

Jenssen, J. I., \& Grave, A. (2002). Does the degree of redundancy in social networks influence the success of business starts-ups? International Journal of Entrepreneurial Behaviour and Research, 8(5), 254267. https://doi.org/10.1108/13552550210448357

Jenssen, J. I., \& Koenig, H. F. (2002). The effects of social networks on resource access and business starts-ups. European Planning Studies, 10(8), 1039-1046. https://doi.org/10.1080/0965431022000031301

Jones, K., \& Tullous, R. (2002). Behaviour of preventive entrepreneurs and perceptions of their financial needs. Journal of Small Business Management, 40(3), 233249.

\section{https://doi.org/10.1111/1540-627X.00053}

Kautonen, T. (2008). Understanding the older entrepreneur: Comparing third age and prime age entrepreneurs in Finland. International Journal of Business Science and Applied management, 3(3), 3-13.

Klyver, K., \& Hindle, K. (2014). The Role of Social Networks at Different Stages of Business Formation. Small Enterprise Research, 15(1), 22-38. https://doi.org/10.1080/13215906.2007.11005830

Lecuna, A., Cohen, B., \& Chavez, R. (2017). Characteristics of high growth entrepreneurs in Latin America. 
International Entrepreneurship Management Journal, 13, 141-159. https://doi.org/10.1007/s11365-016-0402-y

Leković, B., \& Marić, S. (2017). The technological Availability: Incente for Opportunity Entrepreneurship. Strategic Management, 22(3), 11-18. https://doi.org/10.1002/sej.1238

Linan, F, Santos, F.J., \& Fernandez, J. (2011). The influence of perception on potential entrepreneurs. International Enterreneurship Management Journal,7, 373-390. https://doi.org/10.1007/s11365-011-0199-7

Malach-Pines, A., \& Schwartz, D. (2008). Now you see them, now you don't: gender differences in entrepreneurship. Journal of Management in Psychology, 23(7), 811-832. https://doi.org/10.1108/02683940810896358

Morgan, J \& Sisak, D. (2015). The Power of Negative Thinking: A Model of Entrepreneurship, Aspirations, and Fear of Failure. SSRN Electronic Journal, 1-36. https://doi.org/10.2139/ssrn.2547727

Patzelt, H., 6 Shepherd, D.A. (2011). Negative emotions of an entrepreneurial career: Self-employment and regulatory coping behaviours. Journal of Business Venturing, 26, 226-238. https://doi.org/10.1016/j.jbusvent.2009.08.002

Pinillos, M.J, \& Reyes, L. (2011). Relationship between individualist-collectivist culture and entrepreneurship activity: evidence from Global Entrepreneurship Monitor data. Small Business Economics, 37, 23-37. https://doi.org/10.1007/s11187-009-9230-6

Puente, R., Cervilla, M., Gonzalez, C., \& Auletta, N. (2017). Determinants of the growth aspiration: A quantitative study of Venezuela's entrepreneurs. Small Business Economics, 48, 699-726. https://doi.org/10.1007/s11187-016-9791-0

Reynolds, P.D., Camp, S.M., Bygrave, W.D., Autio, E., \& Hay, M. (2001). Global Entrepreneurship Monitor, 2001 Executive Report. Kauffman Centre for Entrepreneurial Leadership.

Reynolds, P.D., Carter, N.M., Gartner, W. B., \& Greene, P. G. (2004). The Prevalence of Nascent Entrepreneurs in the United States: Evidence from the Panel Study of Entrepreneurial Dynamics. Small Business Economics, 23, 263-284. https://doi.org/10.1023/B:SBEJ.0000032046.59790.45

Robichaud,Y, LeBresseur, R., Nagarajan, K.V. (2010). Necessity and Opportunity - driven entrepreneurs in Canada: An Investigation into their Characteristics and an Appraisal of the Role of Gender. Journal of Applied Business and economics, 11 (1), 59-80.

Rusu, V.D., \& Roman, A. (2018). Entrepreneurial Motivation in the European Union Countries: An Empirical Approach. Management Dynamics in the Knowledge Economy, 6(1) 9-31. doi 10.25019/MDKE/6.1.01

Sandhu, M.S., Sidique, S.F., and Shoaib, R. (2011). Entrepreneurship barriers and entrepreneurial inclination among Malaysian postgraduate students. Journal of Entrepreneurial Behaviour \& Research, 17, 428-449. https://doi.org/10.1108/13552551111139656
Shane, S., \& Venkataraman, S. (2000). The promise of entrepreneurship as a field of research. Academy of Management Review, 25(1), 217-226.

https://doi.org/10.2307/259271

Shane, S., Locke, E., \& Collins, C. J. (2003). Entrepreneurial motivation. Human Resource Management Review, 13(2), 257-280. https://doi.org/10.1016/S1053-4822(03)00017-2

Shane, S., Locke, E.A., \& Collins, C.J.(2012). Entrepreneurial Motivation. Human Resource Management Review, 13 (2), 257-279.

Slavić, A., Bjekić, R., \& Berber, N. (2017). The Role of the Internet and Social Networks in Recuirement and Selection process. Strategic Management, 22(3), 36-43.

Sponte, P. M. (2018). Cognitive Performance and Labor Market Outcomes: Evidence from the U.S. Economics, Management, and Financial Markets 13(2): 70-75. https://doi.org/10.22381/EMFM13220185

Stephan, U., Hart, M., Mickiewicz, T., \& Drews, C. C. (2015). Understanding motivation for entrepreneurship. Enterprise Research Centre and Aston Business School: London. UK.

Stoner, C. R., \& Fry, F. L. (1982). The entrepreneurial decision: Dissatisfaction or opportunity. Journal of Small Business Management, 39-44.

Suchart, T. (2017). Factors Influencing Opportunity Driven Nascent Entrepreneurs in Europe and Asia. European Research Studies Journal, 20(3A), 774-782.

Verheul, I, \& Mil, L. (2011). What determinants the growth ambition of Dutch early-stage entrepreneurs? International Journal of Entrepreneurial Venturing 3, 183-207. https://doi.org/10.1504/IJEV.2011.039340

Verheul, I., Thurik, R., Hessels, J., \& Zwan, P. (2010). Factors Influencing the Entrepreneurial Engagement of Opportunity and Necessity Entrepreneurs. Scales Research Reports H201011. EIM Business and Policy Research.

Wagner, J. (2004). Nascent entrepreneurs. The life cycle of entrepreneurial ventures Boon. Germany: Institute for the study of labour.

Wagner, J. (2005). Nascent Necessity and Opportunity Entrepreneurs in Germany. Evidence from the Regional Entrepreneurship Monitor (REM). Working Paper Series in Economics, 10, 1-25.

Watson, J. (2002). Comparing the performance of male and female controlled business: relating outputs to inputs. Entrepreneurship, Theory and Practice, 26(3), 91-100. https://doi.org/10.1177/104225870202600306

Welpe, I. M., Sporrle, M.,Grichnik, D., Michl, T., \& Audretsch, D.B. (2012). Emotions and Opportunities: The Interplay of Opportunity Evaluation, Fear, Joy, And Anger as antecedent of Entrepreneurial Exploitation. Entrepreneurship: Entrepreneurship Theory and Practice, 36, 69-96. https://doi.org/10.1111/j.1540-6520.2011.00481.x 


\section{$凶$ Correspondence}

\section{Renata Amidžić}

National Health Insurance Fund, Serbia

E-mail: renata.amidzic@rfzo.rs 